Rethinking Marxism

A Journal of Economics, Culture \& Society

\title{
Neoliberalism and the Right to Be Lazy: Inactivity as Resistance in Lazzarato and Agamben
}

\section{Tim Christiaens}

To cite this article: Tim Christiaens (2018) Neoliberalism and the Right to Be Lazy: Inactivity as Resistance in Lazzarato and Agamben, Rethinking Marxism, 30:2, 256-274, DOI:

10.1080/08935696.2018.1502310

To link to this article: https://doi.org/10.1080/08935696.2018.1502310

册 Published online: 17 Sep 2018.

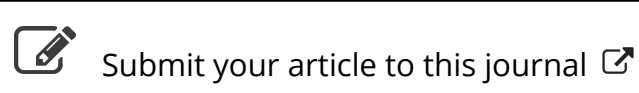

Џ Article views: 83

View Crossmark data ¿ 


\title{
Neoliberalism and the Right to Be Lazy: Inactivity as Resistance in Lazzarato and Agamben
}

\section{Tim Christiaens}

\begin{abstract}
Neoliberalism has installed an unending competitive struggle in the economy. Within this context activists have pushed for a reappraisal of laziness and inactivity as forms of resistance. This idea has been picked up by Maurizio Lazzarato and Giorgio Agamben, but in different ways. This essay first explains the former's appraisal of laziness as a release of potentialities unrealizable under financial capitalism. However, Lazzarato's appraisal of laziness resembles neoliberal theories of innovation because it shares with neoliberalism the conceptual persona of a subject whose potentialities exceed the current status quo. Potentiality is thus not an unambiguous antagonist of capitalism, as Lazzarato suggests. In order to adequately oppose neoliberalism, Lazzarato should question the role of potentiality in capitalism. Agamben has undertaken such a project. The second part of the essay consequently argues that Agamben's philosophy of inactivity as impotentiality is able to circumvent neoliberalism and the society of the spectacle.
\end{abstract}

Key Words: Giorgio Agamben, Impotentiality, Laziness, Maurizio Lazzarato, Resistance

The coming European insurrection will not be an insurrection of energy, but an insurrection of slowness, withdrawal, and exhaustion.

-Franco "Bifo" Berardi, The Uprising: On Poetry and Finance

For many, the contemporary economy has become hard to bear. The entrepreneur of the self is pushed to manage his human capital in an increasingly competitive environment (Foucault 2008) and this 24/7 economy drives many into exhaustion (Malabou 2008; Berardi 20I2; Crary 20I4). Competition leads to incessant economic growth, despite the catastrophic environmental (Lievens and Kenis 20I5) and psychological consequences (Ehrenberg I99I; Stiegler 2009). Contemporary resistance movements respond by pushing for a reappraisal of idleness (Stilinovic 1998; KrisisGruppe 1999; Shukaitis 20I4). The popularity of postworkerist work refusal and exodus (Hardt and Negri 200I; Taylor 20I4) is thus partly explained. 
My essay focuses on two of today's proponents of inactivity: namely, Maurizio Lazzarato and Giorgio Agamben. I first delineate Lazzarato's argument for lazy action, since his account is the most intuitive and aligns with the rhetoric of work refusal in "antiwork Marxism" (Taylor 20I4, 2). Lazzarato argues that contemporary neoliberalism selects some forms of life to the detriment of others in a nondemocratic way. Financial markets decide which lifestyles are viable and which are "not creditworthy." Laziness, as the refusal to work, disrupts this mechanism and consequently opens the possibility for new ways of life outside capitalism. Lazzarato then calls for a society where human beings, instead of finance, decide on the content of life.

Second, I use Agamben's description of the society of the spectacle to point out some flaws in Lazzarato's argument. The first is Lazzarato's promotion of laziness, which is easily integrated within a neoliberal appreciation of potentiality as innovation. This proximity reflects a deeper problem, which is that Lazzarato does not radically question the meaning of subjectivity and potentiality. This critique leads to a development of Agamben's theory of impotentiality and inoperativity as a form of inactive resistance. I first discuss Agamben's theory of resistance as firstorder impotentiality - that is, the suspension of actuality by the performance of actively doing nothing. This impotentiality is, however, co-opted by the society of the spectacle, just like Lazzarato's laziness, and is therefore ineffective. Agamben consequently repeats the exercise by introducing a second-order impotentiality, or the suspension of the suspension of actuality to delineate an inoperative form-of-life.

\section{Lazzarato: Laziness as the Release of Potentiality}

\section{Financial Neoliberalism as an Undemocratic Politics of the Possible}

Lazzarato (2004) starts from a philosophy of potentiality developed in his early works on Gabriel Tarde. The world is made up of Leibnizian monads with each having the capacity to invent possible worlds. "The monad contains in itself an ideal genetic element, an internal force, that is the source of its own modifications, the creation of its own modes of being and its own worlds" (30; my translation). However, Lazzarato distances himself from Leibniz. For the latter, God in the beginning chooses the best of all possible worlds and condemns the others to nonexistence. But according to Lazzarato, the realm of possible worlds coexists with the actual world. Not a transcendent God but the immanent interaction between monads decides continuously which worlds become realities and which stay potential. The world is hence not a divinely preestablished harmony but a polyphony of multiple independent agencies attuning themselves to other agencies.

According to Lazzarato (20I4b, 7I), every social system is just such a selection machine that structures reality to include some ways of life and exclude others. In capitalist society, conduct is incentivized or discouraged depending on its 
capacity to further capital accumulation. Essential to the contemporary neoliberal model of profitability is the hegemony of finance capital (Lazzarato 2015, 214). Instead of exploiting labor through profit, which demands the production of consumer goods, finance can create more money directly out of money. This makes financial neoliberalism seemingly more open toward an optimization of difference instead of assembly-line conformism (209), since profit depends mostly on the uniqueness of human capital. As Foucault (2008, 259-60) wrote, "On the horizon of this analysis we see ... an optimization of systems of difference, in which the field is left open to fluctuating processes, in which minority individuals and practices are tolerated, in which action is brought to bear on the rules of the game rather than on the players." This deviation from the norm is allowed because it provides new investment opportunities.

Financial neoliberalism consequently installs a politics of the possible wherein the financial markets have the largest say. Finance acquires the place of Leibniz's God, deciding which possible world is the best and eliminating the others (Lazzarato 2004, 95). It becomes the evaluation standard for lifestyles. This operation is not politically neutral. Lazzarato (2015, I03) even calls it undemocratic: "Popular sovereignty is conditional, since the only vote that matters is that of the market and financial institution of international governance, which express their 'political' will every day and in real time via the stock market and the spread." If we intuitively define democracy as the idea that those who are subject to a particular rule should also participate in its making, then the power of financial markets to decide on austerity measures or the viability of political decisions is undemocratic. In contrast to industrial capitalism, which was undemocratic in its own way, financial relations of domination are depersonalized (Lazzarato 20I4, 4I). Traditional capitalism was managed by identifiable people, but financial capitalism is run by unaccountable financial traders and computer algorithms. If capital functions as a Leibnizian God selecting the best of all possible worlds, then finance is a deus absconditus.

Since financial transactions are indifferent to the underlying assets traded, current lifestyles are threatened (Lazzarato 2015, I4I). The capitalist selection machine takes profitability as the prime evaluation standard, whereas one might deem some activities valuable even if they do not produce direct monetary value. For instance, proponents of the humanities defend the study of literature, art, and philosophy on the basis of its intrinsic worth (Nussbaum 20I2), but these claims do not figure in a financial evaluation. Financial trading demands the comparability of different assets through monetary equivalence, and all other forms of value are either reducible to money or an externality. The free market thus does not necessarily deliver the democratically most just or most desired result. Contrary to the promise of pluralism and difference exalted by the neoliberals in Foucault's aforementioned quote, neoliberalism only accepts differences that can be monetized, and thus the optimization of difference is illusory. 
Debt serves as the main instrument for creditors to justifiably demand a creditworthy, productive lifestyle from their debtors (Lazzarato 20I2, 37-44; Christiaens 2017). When someone asks for a mortgage, the bank demands certain lifestyle choices in exchange for a lower interest rate. The bank minimizes its risk of nonreimbursement by governing the conduct of its clients. In a similar vein, lending institutions such as the IMF demand structural reforms from indebted populations. This leads people to work beyond their physical and mental capacities and is hence a source of anxiety, depression, and exhaustion (Ehrenberg 199I). Moral guilt is mobilized to justify this governmentality. The fault allegedly lies in the debtor's wrong lifestyle choices, not with the selection machine that prescribes neoliberal forms of life. "Complaints are [thus] turned against oneself instead of relations of power" (Lazzarato 2015, 187). Individuals criticize their own incapacity to work competitively instead of the politics that made them compete. Only the differences that can be turned into financial rent are allowed, so nonfinancialized differences are to be disciplined into conformism. "The semiotic assembly line not only produces knowledge and information, but also attitudes, stereotypes of behaviour, and submission to hierarchies" (Lazzarato 20I4b, 7I).

\section{Rupturing the Logic of Finance}

In order to invent an alternative to the neoliberal general mobilization of energy, Lazzarato $(2014 \mathrm{a}, 5)$ turns to the workerist tactic of work refusal. The underlying idea is that capital exploits life, but the latter is always self-sufficient. Bodies are capable of a lot more than what capital demands of them. The construction of possible worlds originates in the interaction of monads (Lazzarato 2004, 34-5), to which capital is just an external force trying to capture those monads' creativity for its own use. Capital is hence merely an obstacle to potentiality.

According to Lazzarato (2014a, 46; my translation), practicing laziness separates life from the capitalist demands of productivity and consequently releases previously blocked potentialities: "Lazy action is incomparably 'richer' than capitalist action, because it contains potentialities that cannot be reduced to economic production, but that open up to an indeterminate becoming that we have to construct, invent, and sustain." Phenomenologically, Lazzarato equates laziness with the experience of creativity during moments of rest. For instance, some people come up with their most brilliant ideas not while working but while lying in bed at night. When the mind is liberated from subservience to a specific task, thoughts wander in all directions without any concern for functionality. Imagination is left free to roam among ideas. These moments of rest show us a glimpse of what the mind is capable of when it is not put to work for a predetermined project. Laziness is hence not a simple negation of a current situation nor a lethargic doing of nothing but the introduction of heterogeneous potentialities that exceed an actual 
state of affairs. It refuses current identity constructs to reveal a creative potential yet unrealized. "The 'no' addressed to power is no longer the departure for a dialectical struggle but is the opening to a becoming" (Lazzarato 2004, 19; my translation).

The exemplary figure of laziness for Lazzarato (2014a) is Marcel Duchamp. In 1923, Duchamp (1976, 167) stopped making paintings and made his own life into a work of art by exalting laziness and creating multiple identities for himself. For instance, he constructed the personality of Rrose Sélavy, a Jewish woman, and signed some of his works with that name (5I). His obstinate refusal to submit to the demands of productive labor left him the opportunity to elaborate identities or aspects of himself that would not have seen the light of day otherwise. Art hence became a means of self-subjectivation: instead of letting society or capital decide how to form his life, Duchamp developed his own criteria to evaluate life. The capitalist selection machine was disrupted in favor of new, heterogeneous selection procedures.

Duchamp's ready-mades are part of this project. According to Roberts's (2007, 8I-98) labor-theoretical interpretation, the ready-mades expose a dialectic of skill and deskilling in art and, by extension, in all capitalist production. Capitalism tends to technologically deskill workers in ways that minimize their force of resistance. Once the capitalist mode of production comes to require less-skilled laborers, they have less bargaining power due to their interchangeability (83). Duchamp's ready-mades repeat this process for the artist but link it to a liberation of human "totipotentiality" (97). Just as everyone can perform standardized tasks at the assembly line, everyone can buy a urinal and display it as ready-made art. In traditional art, human totipotentiality has been disciplined into a particular craft that requires training, whereas Duchampian deskilling undermines the authority of the skilled artist (II6). However, contrary to the alienation caused by capitalist deskilling, Duchamp's project aims to democratize and liberate the potential of human labor from skilled craft and artistic discipline. No technical skills or artistic virtuosity is required since the material is selected arbitrarily (Lazzarato 20I4a, 27). The end product results not in creative genius exhibited in a work of art but instead reveals only the lack of work Duchamp puts into selecting his material. The ready-made puts laziness on display but not as purely negative inaction. Once human potentiality is no longer subservient to technical discipline, it can freely develop new forms of life.

By reinforcing the impersonal element of artistic production, ready-mades undermine the myth of the genius artist who, as a preestablished ego, realizes a form in matter. They render visible the nonartistic labor behind all works of art (Roberts 2007, I47). In classical paintings, no one knows or cares who made the paint and the canvas, but for Duchamp's ready-mades it is immediately obvious that nonartistic labor is involved in the creation of the artwork. Presubjective social encounters produce works of art, and Marcel Duchamp only serves as the medium. The artist's identity is thus emptied of any preestablished qualities to 
make room for the production of new identities. Marcel Duchamp makes his own life into a blank canvas on which multiple presubjective forces can write their stories.

According to Lazzarato (20I4a, 29), this eventually leads to a transvaluation of all values. Duchamp's artworks are the repetitions of a singular subjective experience through which the members of the public can access a similar realm of laziness in order to develop their own subjectivities (4I). There are no predetermined values to judge the work of art, such as artistic skill or monetary value. This forces the audience members to develop their own standards to value the artwork and, by extension, their own lives. Duchamp intentionally decontextualizes an object and puts it into a new situation in order to contemplate the new possibilities for that object and the lives of the people contemplating it. Lazzarato's proposal of laziness thus solves the two injustices of financial neoliberalism: its undemocratic politics of the possible and its reliance on debt and guilt.

First, if the problem of neoliberal capitalism is an undemocratic politics of the possible, then Duchamp's laziness is an adequate form of resistance, rupturing the current state of affairs with its fixed standards in order to reveal new avenues for self-subjectivation. Ready-mades force audience members to think of their own standards for valuable action, hence emancipating them from the logic of finance. The subject should not be a product of financial decisions but the medium for monads that create new ways of life. Laziness hence disrupts the idea that the world needs a transcendent instance deciding on the best possible world. The standard for evaluating worlds is not centered in one monad but is to be decided by people for themselves.

Second, debt induces guilt because it submits people to preestablished impossible standards of creditworthiness. Life eventually becomes a battle against selfimposed unrealistic performance standards. Laziness shifts these standards to life itself and therefore combats all feelings of inadequacy. "The fight against the debt economy and above all against its 'morality' of guilt, which, in the end, is a morality of fear, also requires a specific kind of subjective conversion ... a second innocence" (Lazzarato 2012, I64). Laziness, refusing the authority of finance as a Leibnizian God, reintroduces innocence because there is no externally imposed norm to sin against. The only norms such living beings abide by are the norms of the beings themselves.

\section{Agamben: Inactivity as the Performance of Impotentiality}

In a footnote to his essay on Marcel Duchamp, Lazzarato (20I4a, 48nI) explicitly distances himself from Agamben's notion of inoperativity. In this section I argue that Lazzarato is right about this dissimilarity but that Agamben's theory of inoperativity is superior to Lazzarato's. I first uncover some problems in Lazzarato's account: namely, that he misrepresents contemporary capitalism, which allows 
for his integration within neoliberal celebrations of innovation, and that he lacks a fundamental critique of potentiality and subjectivation. I then propose Agamben's notion of the society of the spectacle as a more adequate description of contemporary capitalism. The second element, Lazzarato's critique of potentiality and subjectivation, leads me instead to Agamben's theory of impotentiality as resistance. I distinguish between first-order and second-order impotentiality to show the conditions of possibility for resistance.

\section{Contemporary Capitalism as the Society of the Spectacle}

Giorgio Agamben (1998; 2005a) is better known for his critique of sovereignty than that of capitalism, which is undertheorized in his work (Toscano 20II; Whyte 2013, I27). Agamben argues that the construction of a socialized form of life (bios) always demands the inclusive exclusion of natural life (zöè). In the beginning, law and life (zōè) are two completely separate realities, but within bios human beings are assigned a vocation or function (ergon) - that is, a specific potentiality they are supposed to actualize in order to achieve the good life within that community. Natural life is, however, a necessary substrate for the good life in the polis but does not participate in it. Natural life is primarily the object of power relations. Who is worthy of inclusion depends on the discretion of the sovereign, who wields power over the state of exception to suspend the rights of living beings and therefore to strip bios of its qualities and reduce it to "bare life."

When it comes to contemporary capitalism, however, Agamben is heavily influenced by Guy Debord's The Society of the Spectacle (Whyte 2013, I23-58; Abbott 20I4, 190-2). 'Debord (1995) argues that commodity fetishism has gone to such extremes that the reference to any reality beyond the images of exchange value has become meaningless. Objects are split into a use and an exchange value, with the latter being a seemingly independent quality of the object, even though it is the product of human labor. The object hence becomes an image of itself without any reference to its creator or use value (Agamben 2000, 76). For instance, a shopping mall presents numerous phantasmagorical commodities that seem external to the worker who consumes them (Whyte 2013, 129). It does not matter whether the

I. Barkan $(2009,247-8)$ assumes a parallelism between the state of exception and the society of the spectacle. He stresses the fact that in both instances language is reduced to a state of impotentiality. I follow De Cauter (20I2) in claiming that there is a difference, first because the state of exception and the society of the spectacle are confined to different geographical spaces. It makes sense to describe a shopping mall as a spectacle and a detention camp as a state of exception, but not vice versa. Secondly, Agamben frequently invokes impotentiality as a form of resistance against sovereignty but not explicitly against capital. The impotentiality of communication in the society of the spectacle is hidden behind empty talk. The spectacle therefore does not "signify nothing but the inability to communicate" (Barkan 2009, 247) but rather the ability to communicate. The performance of empty talk displays its capacity to mean anything. Only a second-order impotentiality can disrupt this smooth image by exposing the inability to speak (see below). 
gadgets on sale are useful or not; their enchantment suffices to sell them. The society of the spectacle exacerbates this dynamic to such an extent that all human relations are mediated by images (Debord 1995, sec. 4). There no longer exists any directly experienced reality, only enchanting images of commodities.

Agamben $(2007 \mathrm{a}, 87)$ takes this to indicate that the world becomes populated by commodities as pure means: "If the apparatuses of the capitalist cult are so effective, it is not so much because they act on primary behaviours, but because they act on pure means, that is, on behaviours that have been separated from themselves and thus detached from any relationship to an end. In its extreme phase, capitalism is nothing but a gigantic apparatus for capturing pure means." The term pure means no longer refers to a particular end. For instance, the hand gestures that accompany a speech do not convey specific information but only show communicability, only that communication is taking place. If every form of life (bios) determines a specific vocation for humans and things, then pure means disrupt this logic by exhibiting nothing but a potential to have a certain vocation. A gesture does not mean anything specifically, but it can mean anything. By suspending any specific function, pure means keep the potential for numerous meanings.

The society of the spectacle capitalizes on pure means. Commodities with a direct function are substituted for goods that merely project images of multiple potential functions. Instead of assigning particular functions to commodities, the spectacle keeps them in a state of potentiality and suspends each specific actualization. "Products are no longer thought as having immutable characteristics with a definite value, but as evolutional products, susceptible to all potential modifications and capable of offering services with an added value. The material product functions mainly as a support to the distribution of services" (Marazzi 20II, 25; my emphasis). For instance, instead of language being instrumentalized for particular goals, such as to circulate propaganda, today's media convey no specific meaning at all (Agamben 2007a, 88). According to Agamben, the

2. Paolo Virno develops a similar theory of spectacular capitalism in A Grammar of the Multitude (Virno 2004, 59-63) and Déjà Vu and the End of History (Virno 2015, 159-73). He argues that capitalism has always already commodified potentiality as such in the form of labor power. The latter is the commodified human bodily capacity to produce and create, localizable in a past that was never present but that fuels every present with its capacity to instigate the new. The society of the spectacle is the specific form this expropriation of bodily potentiality takes today. It extends the culture industry's mode of production, based on language and communication, to the whole economy. It thereby renders the virtuosic indeterminate potentiality to speak as the dominant commodity. In contrast to traditional capitalism, the society of the spectacle hence makes human potentiality as such "come to the surface, brought into relief as a most concrete phenomenon" (Virno 2015, I4I). In contrast to Agamben, however, Virno does not see impotentiality or inactivity as the appropriate form of resistance, but rather living labor. Similar to Lazzarato, he argues that human potentiality exceeds the bounds of capital accumulation and can hence break the imposed limitations on potentiality for a fuller cultivation of life (Virno 1991, 24). 
contemporary media are bundles of empty talk wherein the consumer decides the meaning. ${ }^{3}$

The contrast to Lazzarato is remarkable. For Lazzarato, neoliberal capitalism is a selection machine that extracts surplus value from actual behavior by excluding unprofitable potentialities. That is why for Lazzarato (2014b, 162-8) the media constitute a machine that makes subjects conform to preexisting codes. Agamben, however, claims that capital today has turned the exhibition of potentiality as such into a profitable resource. Promoting potentiality against neoliberalism might therefore be inappropriate. Lazzarato assumes the existence of preexisting markets to which flexible subjects have to adapt. Finance selects good behavior, and subjects conform. However, neoliberal theories of entrepreneurship, especially Schumpeter's (2008, 8I-6), sharply deviate from this perspective. They mobilize an image of rebellious potentiality similar to Lazzarato's. According to Schumpeter, entrepreneurs are not economic agents who conform to market conditions, looking for the highest possible profits. They are instead willing to forego immediate profits by making risky investments in promising ventures (Bröckling 20I6, 70I; Davies 20I7, 55). For Schumpeter, entrepreneurs are not those who meekly adapt to market demand but are those who successfully transform this demand to fit their own desires. In Lazzarato's terminology, Schumpeter's entrepreneurs break the hegemony of any Leibnizian God deciding which lifestyles are profitable or not. They force a different selection into the capitalist machinery. The resisting subject's potentiality to exceed the bounds of immediate capital accumulation is hence a conceptual persona not only in Lazzarato's critique of neoliberalism but also in the Schumpeterian variants of neoliberalism itself. ${ }^{4}$

3. I do not deny that commodities take on a specific meaning for consumers but that such a specific function is already intended in the act of promoting the commodity. A smartphone is in itself a blank canvas, but each consumer makes it into a particular phone with specific functions. Phones perform their impotentiality to assume any function so that consumers can select the potentialities they prefer.

4. Hardt and Negri (2017, 139-47) have recently acknowledged the proximity between neoliberal entrepreneurship and the creativity of living labor. They argue that the entrepreneurial potentiality to foster new forms of cooperation originally resides in the multitude but that neoliberalism recuperates this potentiality in the figure of the individual hero of capitalist innovation. However, according to Hardt and Negri, this assimilation is always precarious since the multitude at any time exceeds the constraints of private capital accumulation. Hardt and Negri remain in the dark, unfortunately, about how and why this recuperation works, why it is certain a priori that neoliberal entrepreneurship is derivative of the entrepreneurship of the multitude and not vice versa, or why it is self-evident that the multitude would be able to operate a nonrecapturable excess of potentialities. Franco "Bifo" Berardi (2009, 154-5), for instance, refers to the proliferation of depression, suicidality, and the anxieties of precarious workers to question Negri's faith in the multitude's infinite creativity. According to Berardi, there are limits to the multitude's capacity to escape capitalist recuperations of creativity. Once these limits have been crossed, the potentiality of living labor is completely subsumed under capital. Precarious workers can be so forced to permanent creativity in entrepeneurializing their own lives that they are simply too exhausted to create something new beyond capitalist capture. Calling for idle creativity, like Lazzarato does, 
Contemporary research on neoliberal discourse also fits the Schumpeterian narrative (Gillies 20I3; Bröckling 2016, IOI-20). Neoliberalism does not promote passive flexibility toward preexisting markets but rather promotes active agility in transforming these markets. An entrepreneur of oneself does not adapt to the market but exhibits potentials in order to construct new niche markets. Agile entrepreneurs know how to change the selection machine in their favor. It is thus more adequate to describe human market behavior not as the fixed result of neoliberal commands but as the exhibition of potentialities that lack any specific vocation and that are hence polyvalent. Entrepreneurial workers are not trained for a specific job but possess skills usable in multiple settings. "The individual has to become omnipotential" (Micali 20IO, 386). Even laziness is part of the neoliberal discourse on entrepreneurial innovation. For instance, the following quote stems from an opinion article in the Economist but could just as well have been written by Lazzarato: "Creative people's most important resource is their time, particularly big chunks of uninterrupted time, and their biggest enemies are those who try to nibble away at it with e-mails or meetings. Indeed, creative people may be at their most productive when, to the manager's untutored eye, they appear to be doing nothing" ("Schumpeter: In Praise of Laziness" 2013). Being lazy offers an opportunity for entrepreneurs to cultivate potentialities that they can afterward commodify as revolutionizing innovations. Within neoliberalism, laziness is an accepted practice for the opening up of innovative opportunities.

Lazzarato mobilizes the lazy person as a conceptual persona against neoliberalism, but this figure is evidently itself part of the neoliberal imaginary. This jeopardizes laziness as a critical point of view. Lazzarato argues that it opens up a space of creativity in order to counter capitalism, but this space is already functionalized in the entrepreneurial framework. Both exalt laziness as the release of potentiality; for Lazzarato this is nonprofitable potentiality while for neoliberals it is a condition for innovation - that is, the cultivation of temporarily nonprofitable potentialities for future profits. ${ }^{5}$ Behind this mutual celebration of excessive potentiality lies a deeper problem. Lazzarato's proposed practice of resistance mainly shifts the decision on the value of life away from financial markets to the people, but he does not

hence risks working in capital's favor when people are unable to exceed the bounds of capital accumulation.

5. Lazzarato is aware of this affinity between his promotion of potentiality and neoliberalism. In the essay on Marcel Duchamp, he mentions that there is a fine line between the self-subjectivation of potentiality and the integration of this creativity by capital. The art market's instrument of integration is the signature, which turns a ready-made into an artistic commodity with a certain exchange value (Lazzarato 20I4a, 39-40). The autograph makes the work a commodity that is worth more than a simple urinal. In Les révolutions du capitalisme, Lazzarato (2004, 252-6) provides an explanation of this mechanism. Originally, creativity was an extracapitalist process that had no need for capital to function. Capital, however, tried to capture this energy through the paradigm of innovation. By making creativity the basis of economic growth, capitalism has included creativity in its own fabric while maintaining creativity's mysterious nature. Capital needs "innovation" but does not pretend to be able to produce it independently from the commons. 
radically question the category of potentiality, the object of this transfer. He democratizes the politics of the possible but does not believe that there might be something wrong with this politics on a deeper level.

\section{Impotentiality as Resistance}

Agamben studies the relation of potentiality (dynamis) and act (energeia) through a reading of Aristotle's Metaphysics, Book Theta (see Bertozzi 2007; Mills 2008, 29-33; Whyte 2009). Contrary to the Megarians, Aristotle argued that potentialities exist independently of their actualization. The Megarians argued instead that potentialities only exist in their actualization. So, for instance, only when a piece of wood is really on fire is it justified to say that it is flammable. Aristotle rightly pointed out that this is highly counterintuitive given that we think that wood is flammable even if we succeed in avoiding a fire.

Potentiality has some form of existence of its own, but one only perceives it as an absence. For instance, one directly perceives the potentiality to eat only in actively not eating (i.e., a hunger strike). This leads Agamben to investigate potentiality through its opposite: namely, impotentiality (adynamia). A potentiality is only presented as such, without being exhausted in its actualization, when someone exhibits an impotentiality. What differentiates, for instance, a hunger striker from someone not eating while writing is that the former actively exhibits a potentiality to not eat while the latter is simply not eating. Hunger strikers actualize the potentiality to not act. According to Agamben (2007b, 2-3), impotentiality is a specifically human quality. "Human beings are the animals who are capable of their own impotentiality" (Agamben 1999, I82). Agamben argues that the vocation of humankind is to realize potentiality as potentiality and not as actuality. This can only be accomplished through impotentiality, which allows for an actualization that does not exhaust potentiality (Watkin 2013, I42). Impotentiality renders action and potentiality indistinct in the sense that hunger strikers preserve their potentiality to eat in the act by performing their potentiality to not eat. ${ }^{6}$

It is in this context that Agamben refers to laziness in Lafargue and Malevich $(2007 \mathrm{~b}, 6 ; 2015,63)$. Laziness is the performance of the impotentiality to act productively. For instance, when Herman Melville's Bartleby answers the orders of his boss with "I would prefer not to," the lethargy of his inaction is not a simple doing of nothing but the exposure of the impotentiality to work. Instead of a

6. Ziarek (2008) uses the example of the hunger strike to criticize Agamben's theory of impotentiality for lacking a perspective on gender and race while also refusing to see how bare life can be used as a political weapon of confrontation. She is right in stating that most hunger strikes actually serve to enforce the inclusion of a class of people that previously felt excluded from society. Hunger strikes are frequently temporary events of impotentiality in exchange for social recognition. Agamben, however, calls for impotentiality as a way of life, not a temporary practice, since it is the defining characteristic of humankind. This would imply a hunger strike that continues beyond social recognition, as in Franz Kafka's A Hunger Artist (see Christiaens 2015, 126-8). 
direct confrontation or an exodus from power, as Lazzarato envisions laziness, Bartleby opens up a realm where negation and affirmation are rendered indistinct. His formula is neither an outright rejection nor a clear affirmation of his condition.

Agamben $(1999,269)$ mentions that Bartleby had been a clerk in the Dead Letters Office - that is, the institution where undelivered letters are stored. These letters describe realities that could have been but never came to be because the letters did not reach their destination. This is a metaphor for Bartleby's attitude toward the world. He is not interested in the world as it actually is but as it could have been. The actual state of affairs is only one contingent expression of the myriad of possible outcomes of history. Bartleby's impotentiality to decide makes all these potential outcomes equivalent to the actual result. Bartleby's inactive resistance is therefore not a rupture of actuality in order to release unrealized potentialities but a sustained suspension of the difference between the actual state of affairs and potential worlds that did not come to be, based on their shared contingency.

Agamben stretches this state of impotentiality to an "inoperative" life. If a communal form of life (bios) is defined by its activity of assigning functions to human beings and thereby excluding natural life, then the impotentiality to assume a particular function, as Bartleby did, is a step toward emancipation. This suspension of preestablished functions is not a denial of actual vocations but a form of blissful oblivion, as in play (Micali 20IO, 382). When a child plays with a box, the child does not first deny the box's function of storing objects in order to afterwards create new functions; instead, the child forgets that boxes have functions at all. Boxes-turned-toys are not objects that assume a new function after the destruction of an old use; they are realizations of the impotentiality of objects to assume a definite function, thanks to which they showcase a myriad of contingent uses without ever fully assuming one.

\section{Form-of-Life and Impotentiality}

In the society of the spectacle, capital no longer assigns a particular function to commodities but instead suspends their actual functions and exhibits their potentiality as an image in which the consumer is allowed to choose the particular use of the commodity. Whereas the preestablished functions of a traditional cell phone are clear, the contemporary smartphone is a blank canvas of potential usages that consumers can modulate according to their own tastes. Capital transforms all commodities into pure means akin to toys. Agamben's account of inactivity as impotentiality therefore cannot immediately avoid the trap of the spectacle. That is why concepts like "pure means," "inoperativity," or "communicability," normally associated with redemption, also feature in Agamben's description of capitalism (Abbott 20I4, 192). Both refer to the omnipotentiality of pure means. Just as Bartleby's inaction suspends his judgment of the world, capital suspends 
preestablished functions that commodities might have in order to exhibit them as multivalent capacities.

The main difference between the spectacle and Bartleby is the source of impotentiality. In the society of the spectacle, it is capital that suspends actualization in order to maintain potentiality. Consequently, the inoperative being still performs a function (ergon) but one that is emptied of all content. This function is subjected to capital under the relation of a ban, where the law of accumulation is still in force but no longer commands any specific activity. The society of the spectacle consequently performs an extreme version of alienation, separating humanity not only from its productive potentialities but also from its impotentialities: "Nothing makes us more impoverished and less free than this estrangement from impotentiality. Those who are separated from what they can do, can, however, still resist; they can not do. Those who are separated from their own impotentiality lose, on the other hand, first of all the capacity to resist" (Agamben 20II, 45). The capacity to not perform any specific function has itself been turned into a commodity separable from the subject in whom it originates. Capital today separates human beings from their own lives by commanding them to suspend their actual identities in order to expose themselves as a myriad of possible identities for capital accumulation. Just like a smartphone is a blank canvas for which consumers can decide the function by downloading apps, contemporary laborers are tabula rasae for their employers. If impotentiality is the defining characteristic of humankind, then the society of the spectacle, by turning impotentiality into a commodity, separates individuals from their humanity.

Bartleby's inoperative life, on the other hand, originates in an inappropriable realm that cannot be subjected to any willful control (Agamben 1999, 254). His display of impotentiality is not a response to commands that mobilize his impotentiality for capital accumulation. When Agamben (2013, xi; my emphasis) describes inoperativity as a form-of-life, he explicitly describes it as "a life that is linked so closely to its form that it proves to be inseparable from it." ${ }^{77}$ Form-of-life implies a life where impotentiality is not appropriated by the law of capital accumulation,

7. Jessica Whyte overlooks this distinction when she criticizes Agamben's use of the concept of the society of the spectacle. According to Whyte (2013, I28), Agamben proposes a kind of accelerationism as "active nihilism" wherein people should live by the spectacle as a precursor to redemption. This reading is common among Agamben scholars (see Mills 2008, 126-8) but is questionable. Given Agamben's (2013) insistence on the Franciscan opposition to property as a paradigm of new use, it seems unlikely that he neglects commodification or agrees to it in any possible way. I argue instead that the spectacle is a problem left unsolved by the rendering inoperative of bios through impotentiality because the spectacle exploits impotentiality itself. It looks like Agamben promotes the society of the spectacle or sees it as an image of the redemption to come because he uses the same strategy twice. Bios was rendered inoperative through the performance of impotentiality, but this performance was later captured by capital. By performing a second-order impotentiality to render capitalist impotentiality inoperative, form-of-life is installed as a condition in which life and its form are inseparable (see below). 
even if this law prescribes nothing. Bartleby's impotentiality does not serve any goal.

To see an inappropriable impotentiality, imagine someone giving a speech for an audience of managers. He is selling a product by appealing to their needs and desires. The worker uses empty slogans like "thinking out of the box," "performance-enhancing business opportunities," or "peer-to-peer assessment" because they are meaningless. The managers each hear whatever they want to hear. This speech is an excellent example of a spectacle insofar as empty words execute the impotentiality of communication. The speaker is a polished image on display that communicates nothing but communicability. But suddenly his speech falls apart. His voice is coarse due to a cold, and swiftly he is left with no voice at all. Panic takes hold of him, but he only produces some inaudible murmurings.

In fact, not very much has changed. Before, he was saying nothing in the sense of producing empty talk, and now this saying nothing takes the form of no speech at all. Whereas the initial empty talk displays pure communicability but hides its empty nature, the following silence reveals the emptiness of communication taking place in its purest form. The communicative relation between speaker and audience is not completely annulled. The audience members are still eagerly awaiting the next slogan, and the speaker tries to maintain their attention. Communication only consists of a shared sense that communication is taking place, without actual information necessarily being transmitted. The failing voice performs, as it were, the impotentiality of the impotentiality of language. Empty talk communicates nothing in particular but hides this beneath a flood of words. The silent voice, on the other hand, shows that some part of the speaker's body is actively not doing the not-doing it is supposed to do; it fails at the projection of empty talk.

The first-order impotentiality (empty talk) originates ultimately in the law of capital accumulation. The manager talks nonsense because that is profitable. This condition produces a split in the subject insofar as his image becomes an owned commodity separate from his bare life. The second-order impotentiality (silence) disrupting the first-order impotentiality finds its origin in bare life. Some part of the body cannot be integrated into the display of a polished image of impotentiality. Instead of being completely appropriated by capital, the subject maintains an inappropriable element that breaks capitalist alienation. If we take this example further, we can see that the depressed, the exhausted, and the "losers" of neoliberal competitions are in fact prefigurations of redemption. Their lives break down in the face of capitalist exploitation until nothing but bare lives are left.

Agamben's form-of-life idea suggests that we can sustain a more positive relation to this inappropriable or impersonal part of life. Instead of panic, shame, or disgust, we should learn to love this part of ourselves and others (Zartaloudis 2010, 286-7; Whyte 2013, I46-50). "Love is the passion of facticity in which man 
bears this nonbelonging and darkness, appropriating (adsuefacit) them while guarding them as such" (Agamben 1999, 204). This notion of love differentiates mere resisting impotentiality from a redeemed happiness. The intended object of this love is not an actual state of affairs deemed to be the perfect actualization of a potentiality but is the conservation of all potentialities on an equal footing with actuality. For instance, one loves someone not simply for who the beloved is now but also for everyone the beloved could be now (Agamben 1992, 2). The actual beloved is not privileged compared to who he or she could have become. The lover is simply indifferent to the actual or potential characteristics of the beloved because the beloved is valued in this being-thus (Watkin 2013, 95). The beloved does not need to conform to any standard, not even an empty one. The inappropriability of bare life cannot serve any telos.

Consequently, a form-of-life is a life wherein those potentialities that do not fit one's actual identity are not negated but are maintained as impotentialities. They are not hidden as in the managerial speech example but accepted as latent impotentialities. Actuality is hence the always reversible suspension of impotentiality. For instance, being male does not eternally solidify one's identity. It is the suspension of the potentiality to not be male or to be female. One identity does not exclude the others, nor is there anything substantial about masculinity or femininity. An individual is all these identities at the same time; only right now is one more manifest than the others. Any actual state of affairs can thus exist somewhere on the spectrum between male and female depending on how much (im)potentiality of each is actualized. Just like Bartleby opened up the world as a collection of contingent worlds in which the distinction between the "real" world and other possible worlds was suspended, a form-of-life is a lifestyle that deactivates the opposition between potential and actual properties.

In The Time that Remains, Agamben explains this attitude with the Pauline formula "as not" (hōs mè): "But this I say, brethren, time contracted itself, the rest is, that even those having wives may be as not [hōs mè] having, and those weeping as not weeping, and those rejoicing as not rejoicing, and those buying as not possessing, and those using the world as not using it up. For passing away is the figure of this world. But I wish you to be without care" (I Cor. 7: 2932; quoted in Agamben 2005b, 23). Agamben's ideal is a form-of-life in which the actual state of affairs does not depend on the negation of other potential but unrealized outcomes. Weeping should not express sadness to the detriment of happiness, pain, or indifference but should be an activity in which all definite meaning is suspended. The meaning of the activity of weeping does not depend on an individual subject's will but on something inappropiable in the subject that attunes the weeping. This is the only way to do justice to the inappropriable remnant in life, outside of any conscious control. "The messianic vocation is the revocation of every vocation ... nullifying it in the very gesture of maintaining and dwelling in it" (Agamben 2005b, 23-4). 
Agamben (2007a, I4; 2015, I35) also uses Marcel Duchamp as an example of the inoperative not as form-of-life. For Lazzarato, Duchamp ruptures preestablished meanings to force his audience and himself to construct their own values independently of capitalist evaluation standards of profitability. This allows for the cultivation of potentialities as preindividual forces that exceed capitalist market commands. Agamben also stresses that the ready-made is a residue of self-subjectivation in which impersonal forces are allowed to influence subjectivation, but he substitutes the scheme of the anterior rupture of actuality and subsequent release of potentiality for the suspension of the difference between actuality and potentiality. The subjectivity that ready-mades are supposed to produce is not a multitude of different characters but the suspension of each of Duchamp's identities in order to display all the potential egos coexisting as potentialities. Rrose Sélavy is not an actual identity of Marcel Duchamp next to his actual male persona but a potentiality that is allowed to appear because Marcel Duchamp has achieved the impotential to assume any identity. Rrose Sélavy is one of the identities Duchamp could have had but does not have. Marcel Duchamp's face does not communicate a particular personality but only exposes the capacity to assume personalities (Agamben 2000, 9I-IOO). For Agamben (201I, 46-54), personhood is nothing more than a mask (persona) resulting from the need for social recognition. Agamben wishes for the suspension of all masked personalities in order to let the bare identity of individuals exist independently. This does not imply that Agamben aims to destroy all actual personalities but that he argues against the privilege of any actual personality over the potential ones. When Marcel Duchamp shows that he could just as well have been Rrose Sélavy, he demonstrates how to live his life as if he were not Marcel Duchamp.

\section{Conclusion}

Neoliberalism demands that individuals become competitive entrepreneurs. This partly explains the contemporary epidemic of depression, exhaustion, and anxiety. Lazzarato and Agamben propose inactivity to resist this predicament. For Lazzarato, the problem of neoliberalism is the financialized politics of the possible that undemocratically lets finance decide which potentialities can be actualized and which ones are to be excluded. Laziness disrupts this logic by opening up new possibilities to develop other aspects of life when people stop performing the work capitalism demands. Finally, Marcel Duchamp serves as a model for self-subjectivation in which people determine their own standards for a valuable life instead of relying on the financial standards of capitalism.

Agamben's account of capitalism is, on face value, more pessimistic. The society of the spectacle has commodified (im)potentiality itself. This explains why Lazzarato and his neoliberal opponents are similarly enthusiastic about potentiality. Both 
exalt the excess of potentiality over actual market demand, which limits the critical force of Lazzarato's appraisal of laziness. Agamben reinterprets resistance as the performance of impotentiality: that is, the display of actively doing nothing, with Bartleby as the main example. He suspends the difference between the actual but contingent state of the world and its unrealized potentialities. However, the society of the spectacle capitalizes on this suspension to produce a society mediated by images and empty talk. Agamben enables us to interpret inactivity as a form-oflife in which impotentiality is no longer co-opted for profit and bare life and the inappropriability of the world are loved in their contingency. By countering the society of the spectacle with the performance of second-order impotentiality, a new use of the world and the self is revealed.

\section{Acknowledgments}

I wish to thank Professor Toon Braeckman, Professor Stefano Micali, Massimiliano Simons, and Liesbeth Schoonheim for their comments together with the people from the Resistance Conference at the University of Brighton (2016) and the Critical Finance Studies Conference at Southampton (2016) where I presented earlier versions of this paper. I am grateful to my friends and colleagues for contributing to the idle environment indispensable for philosophical creativity.

\section{References}

Abbott, M. 20I4. The figure of this world: Agamben and the question of political ontology. Edinburgh: Edinburgh University Press.

Agamben, G. 1998. Homo sacer. Stanford: Stanford University Press.

. 1999. Potentialities. Stanford: Stanford University Press.

. 200o. Means without end: Notes on politics. Minneapolis: University of Minnesota Press.

- 2005a. State of exception. Chicago: University of Chicago Press.

. 2005b. The time that remains. Stanford: Stanford University Press. 2007a. Profanations. New York: Zone Books.

. 2007b. The work of man. In Giorgio Agamben: Sovereignty and life, ed. M. Calarco and S. DeCaroli, I-IO. Stanford: Stanford University Press.

- 20Ir. Nudities. Stanford: Stanford University Press.

. 2013. The highest poverty: Monastic rules and form-of-life. Stanford: Stanford University Press.

-2015. Le feu et le récit. Paris: Editions Payot and Rivages.

Barkan, J. 2009. Use beyond value: Giorgio Agamben and a critique of capitalism. Rethinking Marxism 2I (2): 243-59.

Berardi, F. [Bifo]. 2009. The soul at work. Los Angeles: Semiotext(e).

. [Bifo]. 2012. The uprising: On poetry and finance. Los Angeles: Semiotext(e). 
Bertozzi, A. 2007. Thoughts in potentiality: Provisional reflections on Agamben's understanding of potentiality and its relevance for theology and politics. Philosophy Today $5 \mathrm{I}$ (3): 290-302.

Bröckling, U. 20I6. The entrepreneurial self. London: SAGE.

Christiaens, T. 2015. De wereld is alles wat het geval kan zijn: Agambens metafysische en politieke interpretatie van potentialiteit bij Aristoteles. De Uil van Minerva 28 (2): II3-32.

- 2017. Debt. In 50 key terms in contemporary cultural theory, ed S. De Cauwer, J. De Bloois, and A. Masschelein. Kalmthout, Belg.: Pelckmans Pro.

Crary, J. 2014. 24/7: Late capitalism and the ends of sleep. London: Verso.

Davies, W. 2017. The limits of neoliberalism: Authority, sovereignty and the logic of competition. London: SAGE.

De Cauter, L. 20I2. Entropic empire. Amsterdam: naioro publishers.

Debord, G. 1995. The society of the spectacle. New York: Zone Books.

Duchamp, M. 1976. Duchamp du signe. Paris: Flammarion.

Ehrenberg, A. 1991. Le culte de performance. Paris: Callman-Levy.

Foucault, M. 2008. The birth of biopolitics. London: MacMillan.

Gillies, D. 2013. Agile bodies: A new imperative in neoliberal governance. Journal of Education Policy 54 (I): 207-23.

Hardt, M., and A. Negri. 20oI. Empire. Cambridge, Mass.: Harvard University Press.

- 2017. Assembly. Oxford: Oxford University Press.

Krisis-Gruppe. 1999. Manifesto against labour. Krisis: Kritik der Warengesellschaft, 3 I

December. http://www.krisis.org/1999/manifesto-against-labour.

Lazzarato, M. 2004. Les révolutions du capitalisme. Paris: Les Prairies Ordinaires.

- 2012. The making of the indebted man. Los Angeles: Semiotext(e).

- 2014a. Marcel Duchamp et le refus du travail. Paris: Les Prairies Ordinaires.

. 20I4b. Signs and machines. Los Angeles: Semiotext(e).

- 2015. Governing by debt. Los Angeles: Semiotext(e).

Lievens, M., and A. Kenis. 2015. The limits of the green economy. London: Routledge.

Marazzi, C. 20II. Dyslexia and the economy. Angelaki I6 (3): 19-32.

Micali, S. 20I0. The capitalistic cult of performance. Philosophy Today 54 (4): 379-9I.

Mills, C. 2008. The philosophy of Agamben. London: Routledge.

Roberts, J. 2007. The intangibilities of form: Skill and deskilling in art after the readymade. London: Verso.

Schumpeter: In praise of laziness. 2013. Economist, I7 August, 58.

Schumpeter, J. 2008. Capitalism, socialism, and democracy. New York: Harper.

Shukaitis, S. 20I4. Learning not to labor. Rethinking Marxism 26 (2): 193-205.

Stiegler, B. 2009. Acting out. Stanford: Stanford University Press.

Stilinovic, M. 1998. In praise of laziness. Moscow Art Magazine, no. 22, 25-6.

Taylor, C. 20I4. The refusal to work: From the postemancipation Caribbean to post-Fordist empire. Small Axe 44 (July): I-I7.

Toscano, A. 20II. Divine management: Critical remarks on Giorgio Agamben's The kingdom and the glory. Angelaki I6 (3): 125-36.

Virno, P. 199I. Cultura e produzione sul palcoscenico. In I situazionisti, ed. G. Agamben, G. E. Debord, E. Ghezzi, L. Passerini, A. Piccinini, F. Poli, F. Scarpelli, et al., I9-26. Rome: Manifestolibri.

. 2004. A grammar of the multitude. Los Angeles: Semiotext(e). 2015. Déjà vu and the end of history. London: Verso.

Watkin, W. 2013. Agamben and indifference. London: Rowman and Littlefield. 
Whyte, J. 2009. "I would prefer not to": Giorgio Agamben, Bartleby and the potentiality of the law. Law Critique, no. 20: 309-24.

. 2013. Catastrophe and redemption. New York: SUNY Press.

Zartaloudis, T. 20I0. Giorgio Agamben: Power, law and the uses of criticism. London: Routledge. Ziarek, E. 2008. Bare life on strike: Notes on the biopolitics of race and gender. South Atlantic Quarterly 107 (I): 89-I05. 